УДК 330.341:32

\title{
ИДЕОЛОГИЯ КАК ЭКОНОМИЧЕСКАЯ КАТЕГОРИЯ
}

\author{
В.Ф. БАЙНЕВ \\ д-р экон. наук, профессор, заведующий кафедрой инновационного менеджмента \\ Белорусского государственного университета, г.Минск
}

\begin{abstract}
Аннотация
Статья посвящена изучению воздействия идеологии на сочиально-экономическую жизнь общества. Показано, что идеология либерально-рыночного индивидуализма, сегодня активно навязываемая Западом прочим странам, есть главная причина их периферийного, подчиненного, кризисного развития. Предложена альтернативная система взглядов, ориентирующая не на максимизацию личной прибыли и потребления, а на реализачию глубинных потребностей общества в ответственном развитии.

Ключевые слова: идеология, идеология рыночного либерализма, функции идеологии, уровни идеологии, западная демократия

Abstract

The article is devoted to distinguishing the impact of ideology on the social and economic life of society. It is shown that the main reason for the peripheral, subordinate, a crisis of development in some countries is the individualistic nature of liberal market ideology being imposed rudely by the Western countries. The author provides an alternative system of ideas focused on the implementation of the underlying needs in responsible development of the community but not of maximizing profits and personal consumption.

Key words: ideology, ideology of market liberalism, functions of ideology, levels of ideology, western democracy

Идеи экономистов и политических мысллтелей - и когда они правы, и когда ошибаются - имеют гораздо большее значение, чем принято думать. В действительности только они и правят миром.
\end{abstract}

Дю. М. Кейнс

\section{ВВЕДЕНИЕ}

Не смотря на то, что последние 25-30 лет в постсоветских странах были декларативно посвящены избавлению от «тоталитаризма» и «идеологического засилья» в социально-экономической сфере, влияние идеологических шор на нашу нынешнюю жизнь ничуть не уменьшилось. Это становится вполне очевидным, если обратить внимание на одно характерное обстоятельство: термины «демократия», «свобода», «права человека», «рынок» в наши дни звучат не менее часто по сравнению со словами «коммунизм», «социализм», «благосостояние трудящихся», «план» в бытность СССР. Это означает, что на рубеже веков произошел отнюдь не отказ от идеологии, а ее кардинальная смена - вместо советской марксистко-ленинской доктрины развития нам с Запада была имплантирована идеология рыночного либерализма, послужившая концептуальной основой для нашей сегодняшней либерально-рыночной модели развития.

Согласно бытующей в народе поговорке, «тело покорно следует туда, куда прикажет голова». Тем самым обыденной человеческой мудростью подтверждается вынесенная в эпиграф данной статьи мысль о том, что идеология и формируемое с ее помо- 
щью мировоззрение, миропонимание людей едва ли не всецело определяют жизнь человека, общества, человечества в целом. История дает немало примеров, когда вера в свою правоту и справедливость, любовь к Отечеству, готовность к самопожертвованию ради будущего своих детей, внуков и человечества в целом позволяла носителям такого мировоззрения с честью выходить, казалось бы, из совершенно безнадежных ситуаций. И наоборот, большие возможности и ресурсы не играли решающей роли в тех случаях, когда люди в рамках навязанной им идеологии делали нечто им несвойственное, противоестественное.

Так, хорошо известно, что в годы Великой Отечественной войны 1941-1945 гг., когда в очередной ополчившийся раз против русского мира Запад, имея решающий перевес в средствах и вооружениях, руками Гитлера пытался покорить и уничтожить наш народ, именно высокий боевой дух и трудовая доблесть советского человека заставили этого подлого, коварного врага капитулировать. Менее чем полвека спустя тот же самый народ-победитель, имея в своем распоряжении самые мощные в мире вооруженные силы и около трети всех природных ресурсов планеты, был легко дезорганизован и дезинтегрирован посредством нескольких простеньких западных сказок о рыночной «войне всех со всеми» как о главном двигателе прогресса. Окончательно сбитый с толку, со сломленной волей, павший духом наш народ почти безучастно взирал на подписание позорного акта о безоговорочной капитуляции перед тем же Западом в Вискулях, на разрушение и унижение Отечества, во имя которого отдали жизни наши великие отцы и деды. И по сей день многие из нас, потеряв инстинкт самосохранения и ответственности за судьбу детей и внуков, словно под гипнозом продолжают безвольно, покорно наблюдать за рыночным разгромом отечественной промышленности, науки, системы образования и воспитания, за постепенной сменой наших традиционных духовно-нравственных ценностей на их западные, зачастую отвратительные, откровенно богомерзкие суррогаты.

Все это убедительно доказывает, что дух человека первичен, все остальное - дело второстепенное, наживное! Ведь если материя вечна и неуничтожима, то вся экономическая, хозяйственная, общественная жизнь сводится исключительно к волевым, энергетическим усилиям по преобразованию вечной материи в требуемые для существования социума формы. Следовательно, формирующая мировоззрение, дух, волю человека идеология - это не просто влияющий на экономику и социум фактор, но ключевая экономическая категория, требующая пристального, углубленного, всестороннего изучения.

Кстати, значимость идеологии хорошо осознается представителями самых различных областей науки. По словам известного современного белорусского политэконома П.С. Лемещенко, «вопрос идеологии всегда привлекал внимание философов, политологов, социологов, юристов. И даже известные в науке исследователи в области естествознания после разработок частных фундаментальных проблем традиционно обращались к такому явлению, как идеология, для осмысления своих открытий. И лишь экономисты, которые в силу своего предмета и используемой методологии, казалось бы, обязаны выразить свое отношение к идеологии, до последнего времени старались ее вообще игнорировать. Подчеркивалось, что не надо заниматься идеологией, а только экономикой...

Если идеология пронизывает все сферы общественно-экономической деятельности человека, то очевидно, что и в процессе анализа этот компонент не должен не только из него исключаться, но и прямо или косвенно имплантироваться в теорию... Поэтому разработка идеологии в контексте экономической теории (и наоборот!), представляется, поможет выйти науке об экономике на новый, более совершенный уровень» [1, с. 145-146]. 
В конечном счете, включение идеологии в перечень центральных экономических категорий и изучение ее в качестве таковой, на наш взгляд, создаст предпосылки для осмысления и решения множества социально-экономических проблем, ныне так больно терзающих не только постсоветские страны, но и всю переживающую глобальную депрессию мировую экономику.

\section{РЕЗУЛЬТАТЫ И ИХ ОБСУЖДЕНИЕ}

Считается, что первая сознательная попытка создания светской, отличной от религии идеологии была предпринята во Франции на рубеже XVIII-XIX веков французским философом и экономистом А. Дестутом де Треси, который в своей работе «Элементы идеологии» ввел в научный оборот сам термин «идеология». Воздействие идеологии на экономическую жизнь общества и рыночного хозяйства в свое время изучали С. Вайнтрауб, У.Дж. Самуэльсон, Г.Л. Шэкл и др. Однако принято считать, что впервые попытку взглянуть на идеологию как на важнейший общественный институт, существенно влияющий на экономику, предпринял Д. Норт в рамках институционального направления экономической теории. Немало новых интересных мыслей на эту тему можно найти и в работах современных российских и белорусских ученых А.А. Зиновьева, П.С. Лемещенко, П.Г. Никитенко, Ю.М. Осипова, И.А. Руденкова С.Ю. Солодовникова, А.И. Субетто и др. [1, 2, 3, 4, 5, 6].

В самом общем смысле идеология - это вся та совокупность информации, которая используется для целенаправленного воздействия на людей с целью управления ими в интересах тех, кто организует указанное воздействие. При этом следует различать светские и религиозные идеологии, которые хотя и имеют одну и ту же конечную цель - управлять людьми сообразно с интересами правящих политических, экономических, религиозных, интеллектуальных элит, однако, существенно разнятся тем, каким образом эта цель достигается. Так, если идеология апеллирует преимущественно к разуму человека, то религия - исключительно к его чувствам, эмоциям и вере, которая, как известно, не требует каких-либо обоснований, доказательств и прочей дополнительной аргументации. Светские же идеологии, претендующие на роль действенного инструментария для познания и преобразования окружающей действительности, обычно стремятся облачаться в научные одежды. А сегодня, когда люди уже не мыслят своего существования без достижений научно-технического прогресса, светские идеологии стремятся не просто приспособить науку к своим интересам, но и выглядеть полноценной наукой.

С другой стороны, идеология, не смотря на ее пристрастие рядиться в научные мантии, отличается от науки. По мнению известного советского и российского социолога А.А. Зиновьева, «наука не есть идеология, а идеология не есть наука. Они различаются по целям, по средствам и по отношению к реальности. Задача науки - познавать мир, поставлять обществу знания обо всем, что интересует людей и важно для их жизни. Задача идеологии - не открытие новых истин о природе, обществе и человеке, а организация общественного сознания, управление людьми путем воздействия на их сознание и приведение их сознания к некоторому общественному стандарту, воспитание масс населения в духе, необходимом для самосохранения общества, выработка стандартных «координат» ориентации людей в окружающем мире» [6, с. 78].

Исходя из этого, можно выделить несколько функций, которые выполняет идеология во всякой социально-экономической системе. Прежде всего, и это первая, главная функция, она является инструментом, средством управления большими массами людей в соответствии со стратегией, моделью, планом развития, которые отвечают интересам господствующих экономических, политических, интеллектуальных элит, име- 
ющих соответствующие административные, материальные, технические возможности воздействовать на население.

В связи с этим можно подискутировать по поводу встречающегося в учебной литературе утверждения о том, что основная функция идеологии состоит в формулировании общей стратегии развития [1, с. 148]. Дело в том, что стратегия и план развития, как правило, уже имеются в головах у правящих элит, а идеология - это всего лишь механизм, с помощью которого они реализуются. При этом очень часто интересы господствующих кланов не совпадают с интересами народа, а потому громко декларируемые идеологией цели могут иметь мало чего общего с истинными целями де факто реализуемой в стране стратегии развития. Типичным примером этого является идеология перестройки в бывшем СССР, на словах декларировавшая построение «социализма с человеческим лицом», а на деле служившая инструментом претворения в жизнь стратегии его (и социализма, и СССР) уничтожения с конечной целью «прихватизации» общенародной собственности правящими кланами. С учетом этого становится вполне понятно, почему народы бывшего СССР вместо обещанного и ожидавшегося ими рыночного рая оказались в аду бандитского, полукриминального олигархического капитализма с его нескончаемыми кризисами, дефолтами, девальвациями, инфляционными шоками, терактами, «майданами», кровопролитными межэтническими и даже межгосударственными вооруженными конфликтами.

Следует признать, что всякая идеология состоит как минимум из двух составных частей, взаимосвязанных компонент. Первая компонента, внешняя, предназначенная для всеобщего употребления, служит для формирования у большого количества обычных людей неких типовых, унифицированных представлений об окружающем их мире, что делает предсказуемым, а значит, легко управляемым их поведение в стандартных, типичных ситуациях. Вторая же компонента идеологии, внутренняя, наоборот, является герметичной, закрытой, предназначенной для внутреннего пользования исключительно теми, кто управляет, манипулирует поведением людей в своих интересах.

Как известно, вплоть до XX века мир представлял собою совокупность конкурирующих, борющихся друг с другом за ограниченные средства существования суверенных национальных государств. Их национальные политические, экономические, интеллектуальные элиты, связывая будущее своих детей и внуков со своими государствами, были кровно заинтересованы в том, чтобы эти страны и населяющие их народы усиливались, развивались и тем самым увеличивали возможности господствующих элит, укрепляли их доминирующее положение. При этом обе описанные выше компоненты исповедуемой национальными элитами идеологии, как внешняя, так и внутренняя, возможно, различаясь в деталях, в целом были подчинены общей цели развития и прогресса страны и населяющих ее народов.

Сегодня же, в условиях глобализации, подразумевающей свободное трансграничное перемещение капиталов, западные страны предоставили политическим и экономическим элитам периферийных государств широкие возможности для вывода в центр «заработанных» ими на периферии средств и дальнейшего обустройства там. Диктуемые тем же Западом принципы выборной демократии, когда пребывание у власти политических, а значит, и экономических элит периферийных стран законодательно ограничено одним-двумя сроками властных полномочий, объективно стимулируют эти элиты к превращению в компрадорские кланы. Связывая свое будущее уже с богатым Западом, такие властные временщики-компрадоры не заинтересованы в процветании тех периферийных стран, где они временно находятся у руля. Их истинная цель успеть обогатиться за короткое время пребывания у власти, вывести свои «заработанные» таким образом капиталы на Запад, успеть выучить в престижных западных вузах своих детей, а по истечении срока властных полномочий и самим выехать вслед за ка- 
питалами и детьми. При этом богатый Запад продолжает богатеть за счет дальнейшего разорения и без того бедных периферийных стран.

В этом случае различия между внешней и внутренней компонентами идеологии, насаждаемой компрадорскими, коррумпированными, мародерствующими кланами в периферийных странах, разительны. Например, ныне активно навязываемая странам бывшего СССР идеология рыночного либерализма во всеуслышание декларирует о внешне весьма привлекательных идеалах частной собственности, предпринимательской свободы, равенстве возможностей в условиях либеральной рыночной экономики, живительной силы свободной конкуренции как двигателе развития и т.п. Однако все эти громкие и красивые, выставляемые на всеобщее обозрение лозунги, призванные обосновать целесообразность и необходимость рыночных реформ и, в конечном счете, подвигнуть людей к их реализации, есть всего лишь видимая, надводная часть идеологического айсберга. При этом те, кто столь настойчиво пропагандируют, навязывают, насаждают людям перечисленные идеалы и всеми правдами и неправдами пытаются продавить рыночные реформы, тщательно скрывают, что их единственной конечной целью является «прихватизация», а в итоге - сдача по дешевке национальных активов иностранцам. В частности, уже является достоянием общественности тот факт, что, например, в России в процессе приватизации 1990-х годов общенародная собственность досталась их новым хозяевам лишь за 1,5-5 \% их реальной стоимости, то есть рыночная цена приватизируемых активов была занижена в десятки раз [7, с. 12]. В итоге, по оценкам даже тех, кто стоял у истоков либерально-рыночных реформ и являлся их идеологом, сегодня до 70 \% российской экономики принадлежит иностранцам [8].

Иными словами, скрытая, подводная часть либерально-рыночного идеологического айсберга подразумевает быстрое, баснословное обогащение небольшой группы людей, жаждущих «отнять и поделить» общенародную собственность под прикрытием внешне привлекательной болтовни о чудотворной силе частной собственности, рыночной экономики и свободной конкуренции. Ведь сегодня уже ни для кого не секрет, что «прихватизация» - это один из наиболее «крутых» видов бизнеса, по своей прибыльности-рентабельности намного опережающий торговлю наркотиками, оружием, алкоголем и уступающий разве что «полиграфическому бизнесу» ФРС США по изготовлению и сбыту долларов. И действительно, именно благодаря «прихватизации» бывшие научные сотрудники с мизерными окладами в одночасье стали долларовыми мультимиллионерами и миллиардерами.

В крайнем же случае, когда господствующим чиновничьим кланам не удается непосредственно самим поучаствовать в «прихватизации», они, прикрываясь еще одним весьма распространенным рыночным мифом о «чудотворной» силе иностранных инвестиций, организуют (разумеется, небескорыстно) масштабную сдачу национальных активов «долгожданным» иностранным инвесторам за бесценок. В итоге умеющий отблагодарить за подобные услуги Запад продолжает богатеть, народы же постсоветских стран имеют тотально коррумпированные, компрадорские государства, разбазаривающие их национальные богатства, выводящие на Запад средства от их распродажи и тем самым обескровливающие, разрушающие промышленный, научно-технический, образовательный потенциал наших стран. Как следствие, аморальная торговля национальными интересами (коррупция) как образ существования и смысл жизни прозападных компрадорских элит в периферийных странах заставляют их, опираясь на свободные (то есть свободно покупаемые) СМИ, возводить в норму беспринципность, безнравственность, отрицание и глумление над высшими, отличными от примитивных запросов плоти, смыслами существования человека. Сознательно создавая вокруг себя атмосферу всеобщей безнравственности, такие элиты как бы нивелируют различия между добром и злом, в результате чего их продажность и мародерское поведение выглядят всего лишь как стремление заработать, свойственное всякому рационально мыс- 
лящему экономическому человеку. Именно этим объясняется тот культ обогащения, потребления, похоти, роскоши, насилия, всевозможных извращений и прочей безнравственности, который круглосуточно буквально насаждают, вдалбливают в сознание людей наши «свободные» СМИ.

Вторая функция идеологии заключается в том, что она выступает в качестве механизма, реализующего ту или иную степень интеграции, единения общества. Здесь также следует подвергнуть ревизии общепринятую в учебной литературе точку зрения, согласно которой идеология однозначно «служит объединяющей и цементирующей основой общества» [1, с. 146]. В частности, та же идеология рыночного либерализма хотя и объединяет умонастроения людей вокруг перечисленных выше либеральнорыночных идеалов и ценностей, однако, пропагандируя и организуя рыночную «войну всех со всеми», де факто является могучим средством дезинтеграции, разобщения, «атомизации» социума. Что касается правящих кланов, то для них внутренняя, герметичная, закрытая от всеобщего обозрения компонента либерально-рыночной идеологии, действительно, подразумевает сплоченность, монолитное единство в достижении их главной заветной цели - «отнять и поделить» и, в конечном счете, сдать западному капиталу собственность народа, ради этого сознательно дезинтегрируемого и «атомизируемого» посредством рыночных демократических идеалов.

Здесь следует специально оговориться и насчет так называемых демократических ценностей - свободы слова, печати, права избирать и быть избранным и т.п. Дело в том, что в условиях капитализма, когда человек стоит ровно столько, сколько у него денег, фактический объем демократических прав и свобод индивидуума определяется не масштабами разглагольствований об этих самых демократических идеалах, а размером его кошелька. Только совсем наивный может вообразить себе, что объем демократических прав и свобод одинаков у миллиардера и, положим, у школьного учителя. Олигарх, имея возможность финансировать политические партии, парламентские фракции и даже президентские избирательные кампании, владея теле- и радиовещательными компаниями и с их помощью формируя на свое усмотрение общественное мнение, влияет на политическую жизнь неизмеримо больше, нежели рядовой избиратель с его одним-единственным избирательным бюллетенем в кармане. Иными словами, сегодня основной демократический принцип «один человек - один голос» трансформировался в уродливое «если у тебя нет миллиарда, ты никто и ничто».

В условиях капитализма демократия является всего лишь механизмом, с помощью которого экономическая власть конвертируется во власть политическую. В связи с этим вспоминается откровенное высказывание на ту тему весьма известного в недавнем прошлом российского олигарха Б.А. Березовского о том, что «демократия - это власть крупного капитала», и только. Вот почему демократические преобразования и либерально-рыночные реформы, во-первых, с подачи Запада всегда идут, что называется, в одной упряжке, а во-вторых, закономерно порождают такое уродливое явления как олигархия, а значит, коррупцию, продажное чиновничество и компрадорское, мародерское государство.

Основная иллюзия навязываемой Западом выборной демократии состоит в том, что выборы в периферийных странах при прочих равных условиях всегда выигрывают те кандидаты, кого морально и, главное, финансово поддерживает глобальная метрополия. Иными словами, именно институт выборной демократии служит средством приведения к власти и/или легитимации в периферийных странах подконтрольных Западу местных компрадорских политических и экономических элит, торгующих в его пользу национальными интересами. Там же, где этот институт по тем или иным причинам благоразумно блокирован или его функционирование искусно имитируется, используются другие, более радикальные методы приведения к власти продажных, компрадорских прозападных кланов - всевозможные «тахриры», «майданы» и «плошчи», финансируе- 
мые Западом из средств, бесцеремонно выделяемых им на повсеместное «развитие» демократии. Если же и этот механизм смены элит не срабатывает, то Запад прибегает к прямой коллективной военной агрессии, как это было в Югославии, Афганистане, Ираке, Ливии, Сирии и т.д. После приведения к власти прозападных компрадорских элит любым из этих способов периферийная страна превращается в донора дешевых природных, финансовых, интеллектуальных ресурсов для процветающего за счет периферийного мира Запада [9].

Точно так же нельзя однозначно согласиться и с другой обозначенной выше точкой зрения А.А. Зиновьева (в целом справедливой и нами разделяемой, однако, быстро устаревающей в условиях глобализации) по поводу того, что идеология выполняет функцию самосохранения общества, народа. К сожалению, опыт республик бывшего СССР последней четверти века доказывает, что ныне господствующая там идеология демократии и рыночного либерализма не только не обеспечивает самосохранение проживающих в этих странах народов, но является доктриной их коллективного самоубийства. С учетом этих произошедших изменений следующую, третью по счету функцию идеологии следует сформулировать так - обоснование целесообразности, апологетика, сохранение и укрепление установленного господствующими элитами порядка (режима) и, соответственно, их власти. При этом не следует путать самосохранение и укрепление властных элит с самосохранением и укреплением общества, насущные чаяния которого сегодня сплошь и рядом приносятся в жертву интересам компрадорских, откровенно мародерствующих правящих кланов, о чем подробно шла речь выше.

Четвертая функция идеологии связана с тем, что она может быть использована и в последнее время сплошь и рядом применяется в качестве эффективного «оружия массового поражения», мощного средства межгосударственной борьбы, цель которой укрепление господства одних стран, входящих в так называемый глобальный центр (глобальную метрополию), над всеми прочими, периферийными, зависимыми, полуколониальными странами. С учетом этого сегодня применительно к каждой конкретной периферийной стране можно вести речь не о двух описанных выше компонентах идеологии, а о трех ее составных частях (уровнях).

Первая компонента, предназначенная для широких масс, призвана пространно разглагольствовать о демократии, правах и свободах индивидуума, живительной силе конкуренции, «невидимой руке» либерального рынка, якобы заставляющей частный бизнес эффективно решать общественные проблемы и т.д. Вторая компонента, предназначенная для местных элит периферийных стран, нацеливает их на инициацию и осуществление демократических либерально-рыночных реформ, ядром которой является «прихватизация» и создание наиблагоприятнейших условий для иностранных инвесторов, то есть сдача за бесценок национальных активов западным странам. Третья компонента идеологии, которой подчинены обе предыдущие ее составные части, имеет глобальный, наднациональный характер и исповедуется политическими и экономическими элитами ведущих западных стран - глобальной метрополии. Их конечная цель - установление власти западного, прежде всего, долларового капитала над активами всего мира посредством соответствующего идеологического воздействия на местные элиты периферийных стран, которые, в свою очередь, оказывают соответствующую идеологическую обработку местного населения на своем уровне.

Конструкция и функционирование такого глобального трехуровневого идеологического механизма (рисунок 1) сводится к следующему: на первом - низовом - уровне население периферийных стран должно свято верить в светлые идеалы демократии и свободной рыночной экономики и желать демократических рыночных реформ; на втором - промежуточном - уровне политические и экономические элиты периферийных стран должны быть уверены, что за свои услуги по осуществлению демократических рыночных реформ на местах, то есть за организацию «прихватизации» и сдачу нацио- 
нальных активов долларовому капиталу, их самих и их детей ждет последующее безбедное существование в благополучных западных странах; на третьем - верхнем уровне глобальные элиты, терпеливо достраивающие подобный идеологический механизм путем финансирования выборной демократии и «цветных революций» в периферийных странах, устанавливают контроль над их национальными активами и тем самым прокладывают себе путь к мировому господству.

Следует заметить, что в современных условиях активного создания межгосударственных союзов и блоков типа Европейского союза (ЕС), промежуточных этажей (уровней, компонент) глобального идеологического механизма может быть несколько. Например, в рамках ЕС можно выделить идеологию на уровне местных элит рядовых стран союза и идеологию на уровне наднациональных элит Еврокомиссии, Европарламента, Европейского центрального банка, которые, однако, все равно оказываются жестко вмонтированными в глобальную идеологическую вертикаль.

Анализируя количественные и качественные характеристики идеологий, следует отметить, что идеологических учений было много в прошлом, немало их существует и в настоящее время. Некоторые идеологии влияют на весьма ограниченный круг людей и непродолжительное время, другие демонстрировали и продолжают демонстрировать свой поистине глобальный масштаб. Так, к числу идеологий глобального, эпохального характера следует причислить, прежде всего, мировые религии, а также буржуазную идеологию рыночного либерализма и марксизм-ленинизм.

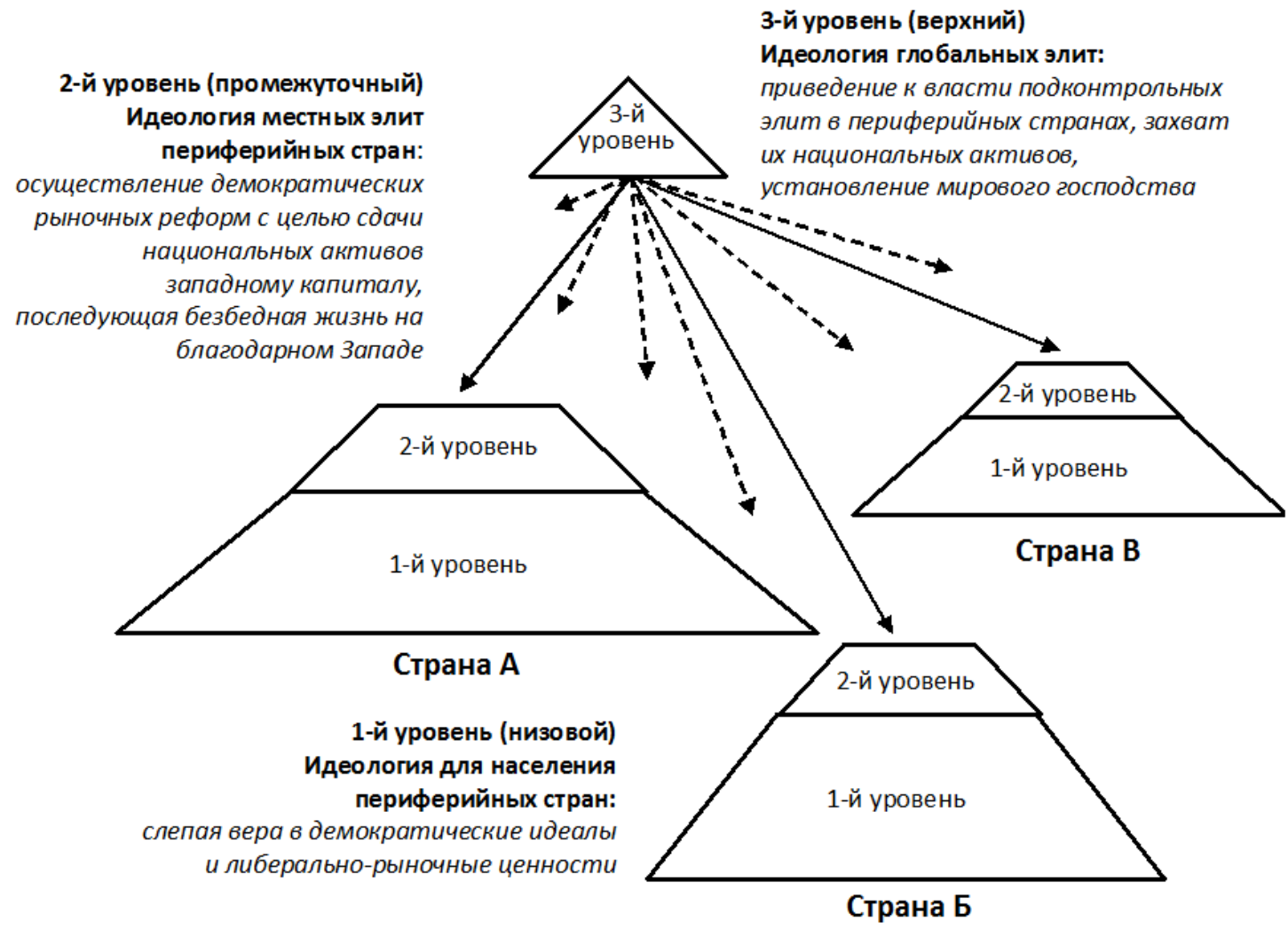

Рисунок 1 - Современный глобальный многоуровневый идеологический механизм как инструмент установления мирового господства владельцами долларового капитала

Что касается идеологии рыночного либерализма, то основоположником философии буржуазного, капиталистического способа производства, а по сути дела идеологии частнособственнической либеральной конкурентно-рыночной экономики является А. Смит. Изложенные в его «Исследовании о природе и причинах богатства народов» (1776 г.) фундаментальные идеи о частной собственности и свободной конкуренции как источни- 
ках богатства и развития и о «невидимой руке» рынка, якобы направляющей частный бизнес на достижение общественно значимых результатов, служили и служат путеводной звездой множеству экономистов. Идеология рыночного либерализма является той магистралью, вдоль которой и вблизи которой получили свое развитие научные теории и школы, исследующие те или иные аспекты, ограничения, проблемы функционирования конкурентных рынков и рыночного хозяйства в целом. Сказанное в той или иной мере справедливо по отношению к научным воззрениям представителей классической экономической школы (Ж.Б. Сэй, Ф. Бастиа, Ж.С. Сисмонди, Д. Риккардо, Н. Сениор и др.), маржинализма (А.О. Курно, Г.Г. Госсен, У.С. Джевонс, К. Менгер, Л. Вальрас, В. Парето, А. Маршалл, Д.Б. Кларк, Ф. Визер, О. Бем-Баверк и др.), неоклассического, в том числе неолиберального и монетаристского направлений экономической мысли (Ф. Хайек, М. Фридмен, П. Самуэльсон, Ф. Бем, В. Ойкен и др.), исторической школы (Ф. Лист, К. Книс, Г. Шмеллер, А. Вагнер, В. Зомбарт, М. Вебер и др.), кейнсианства (Дж.М. Кейнс и др.), «старого» и нового институционализма (Т. Веблен, Дж. Коммонс, У. Митчел, Дж.М. Кларк, А. Берли, Г. Минз, Д. Норт, Дж. Гэлбрейт, Р. Хайлбронер, Р. Коуз и др.). И даже представления в рамках теории «социального рыночного хозяйства» (Л. Эрхард и др.), которую нередко рассматривают в качестве самостоятельной идеологии «третьего пути», находятся в том же русле изучения функционирования рыночных механизмов, хотя и при весьма жестких ограничениях.

Следует согласиться с мнением уже упоминавшегося выше профессора П.С. Лемещенко, считающего: «абсолютно неверным утверждение, что идеологии была подвержена только социалистическая (коммунистическая) система. Самая сверхлиберальная политико-экономическая система также пронизана общей идеей, как и ее противоположность, например, система жестко централизованного устройства... Идеология - не какой-то инородный элемент экономики, от которого следует и можно избавиться. Идеология представляет собой внутренний компонент любой социальноэкономической системы. Более того, эффективной может быть модель экономики, имеющая свою центральную идею и осознанное ее выражение, которая поддерживается большинством граждан как потребителей, производителей, избирателей, политической, научной и культурной элиты» [1, с. 146-147].

Если попытаться выделить ту предельно общую «центральную идею», которая объединяет все перечисленные выше и другие западные экономические школы и теории, то она может быть выражена формулой:

\section{Максимизация индивидуального потребления и удовольствий = Эгоистичный индивидуализм + Борьба за средства существования.}

Приходится признать, что едва ли не вся экономическая мысль Запада исходила и продолжает исходить из аксиомы-постулата, согласно которому всякий-каждый стремится к максимально полному удовлетворению своих личных, индивидуальных потребностей, к получению удовольствий и наслаждений. При этом считается, что потребности индивидуума по мере их удовлетворения лишь возрастают, а значит, являются безграничными. Доступные же ресурсы для удовлетворения бесконечных запросов человека, наоборот, ограничены, более того, они дефицитны. В подобных объективно стесненных условиях именно «жажда потребления» и «эгоистичный индивидуализм» мобилизуют людей на жесткую, бескомпромиссную борьбу друг с другом за доступ к ограниченным, дефицитным ресурсам, именуемую в экономической теории «конкуренцией». Таким образом, конкурентная борьба, которую многие экономисты воспринимают в качестве базовой, центральной категории идеологии рыночного либерализма, ныне безоговорочно торжествующей в глобальном масштабе, является всего 
лишь вынужденным, неизбежным следствием такого проявления глубинных качеств человека как жажда потребления и удовольствий.

Именно неуемное стремление к максимально полному удовлетворению безгранично растущих потребностей человека является тем главным двигателем западной цивилизации, который принуждал и продолжает принуждать ее к захвату колоний, организации «цветных революций» и прямых военных агрессий в суверенные страны. Именно жажда потребления лежит в фундаменте и нынешней идеологии глобализации, декларирующей распространение либерально-рыночных принципов хозяйствования на весь мир и подразумевающей создание благоприятных условий для захвата долларовым капиталом национальных активов других стран. Сегодня можно воочию наблюдать, как под прикрытием еще одной современной идеологии борьбы с мировым терроризмом западные страны, движимые все тем же стремлением к максимизации потребления, бесцеремонно вторгаются в суверенные страны, жаждая получить доступ к их природным богатствам.

Таким образом, все перечисленные выше научно-теоретические воззрения и концепции, не смотря на их кажущееся разнообразие и даже кардинальные различия, находятся в русле одной и той же системы мировоззренческих ценностей, которую условно можно обозначить как «идеология западнизма». В ее основе лежит приведенная выше формула, согласно которой цель всякой экономической и прочей активности - стремление к личному потреблению и вкушению удовольствий, порождающее эгоистичный индивидуализм и бескомпромиссную конкурентную борьбу индивидуумов за дефицитные средства существования.

Следует пояснить, что в идеологии западнизма, рассматривающей человека в качестве стремящегося к наслаждениям потребителя, конкурентная борьба - это не просто неизбежный и естественный, то есть предопределенный самой природой процесс, но главный источник развития, двигатель социально-экономического прогресса. Дело в том, что активно насаждаемая Западом периферийному миру идеология рыночного либерализма, как и всякая любая другая светская идеология, опирается на ряд научных теорий и школ. При этом краеугольным камнем в его научно-теоретическом фундаменте является социал-дарвинизм, объявляющий двигателем прогресса характерный для дикой природы и потому как бы «естественный» принцип «Сильные пожирают слабых».

Как известно, в основе социал-дарвинизма лежит учение английского натуралиста Ч. Дарвина (1809-1882) об эволюции жизни, согласно которому прогресс от простейших микроорганизмов вплоть до приматов и человека осуществился благодаря беспощадному естественному отбору (конкуренции) [10]. Для идеологии рыночного либерализма данная система взглядов послужила научным основанием идеи всеобщей универсальной конкуренции как источника развития, ибо именно конкуренция выявляет сильнейших и оставляет их под солнцем.

В свое время древнеримский комедиограф Т. Плавт (254 г. до н.э.-184 г. до н.э.) предложил человечеству формулу «Человек человеку волк», которая, благодаря социал-дарвинизму, обрела статус научно обоснованного факта. Один из наиболее последовательных сторонников социал-дарвинизма английский социолог Г. Спенсер (1820$1903)$ перевел на научный язык вышеприведенное выражение Т. Плавта следующим образом: «Универсальный закон природы состоит в том, что существо, недостаточно энергичное, чтобы бороться за свое существование, должно погибнуть». Еще более точно выразил глубинную мировоззренческую сущность нынешней идеологии либерально-рыночного индивидуализма немецкий философ Ф. Ницше (1844-1900) своим императивом «Падающего подтолкни!».

Важно понимать, что логика социал-дарвинизма и основанного на нем рыночного либерализма весьма незамысловата, а потому понятна и близка всякому обывателюиндивидуалисту - если не мешать сильным, то они уничтожат всех слабых и останутся 
только сильные - это-де и есть развитие! Таким образом, свободная рыночная стихия и беспощадная, ничем не ограниченная конкуренция объявляются идеологией рыночного либерализма наивысшими ценностями цивилизации. Из необходимости организовать эту самую свободную конкуренцию вытекают все те типовые рекомендации, которыми Запад на протяжении последних десятилетий снабжает страны бывшего СССР: приватизация, экономическая открытость внешних границ, развитие малого и среднего бизнеса, свободное ценообразование, максимально полное изгнание государства из экономики и т.п.

Однако, как и любая другая идеология, рыночный либерализм взял из учения Ч. Дарвина не все, а только то, что ему (либерализму) было выгодно и нужно. Как известно, этот английский ученый значительную часть своей жизни посвятил изучению так называемых социальных инстинктов у животных. Он отмечал, что большинство из них предпочитают спасаться от врагов, охотиться, мигрировать не поодиночке, а стаями, стадами, косяками, роями и т.д. Им описаны примеры, когда животные, следуя социальным инстинктам, демонстрируют не только взаимное пожирание, но и взаимопомощь. Позже российским ученым П.А. Кропоткиным об этом была написана целая книга под говорящим само за себя названием «Взаимная помощь как фактор эволюции» [11].

Распространив результаты своих исследований о социальных, общественных инстинктах на человеческое общество, Ч. Дарвин недвусмысленно указывал, что те нации (расы), которые следуют главному принципу дикой природы, согласно которому сильные в конкурентной борьбе уничтожают слабых, являются низшими, варварскими. А те народы (расы), которые придерживаются принципа коллективизма и взаимопомощи, он называл высшими, цивилизованными. При этом Ч. Дарвин пришел к выводу, что варварские народы будут полностью зависимы от цивилизованных в силу того, что высшее, развитое всегда господствует над низшим, примитивным [12, с. 89-110, 421-422]. Разумеется, идеологи рыночного либерализма, проповедующие нам принцип свободной конкуренции «laissez-faire» как бескомпромиссной «войны всех со всеми», предпочли забыть об этом направлении исследований Ч. Дарвина. Это и понятно, ибо наличие общественных инстинктов даже у животных обесценивает стержневую идею либерально-рыночной доктрины развития о том, что конкуренция как «война всех со всеми»главный двигатель прогресса человечества.

Как это уже отмечалось выше, еще одной светской идеологией глобального масштаба является марксизм-ленинизм, кардинально изменивший мир в XX веке. Если в идеологии западнизма центральной идеей является рассмотрение человека в качестве эгоиста-индивидуалиста, жаждущего максимально полного удовлетворения своих безграничных потребностей, то в марксизме-ленинизме человек, наоборот, выступает как солидарный коллективист, сознательно жертвующий своим личным потреблением во имя более возвышенных идеалов братства и справедливости, ради благополучия будущих поколений и человечества в целом.

Не смотря на то, что сегодня указанная стержневая идея марксизма-ленинизма у многих вызывает непонимание и даже отторжение, советская идеология на примерах бывшего СССР и современного Китая доказала свою жизнеспособность. Среди достижений советской цивилизации не только наша Великая Победа, искусственный спутник Земли и Юрий Гагарин, но и вторая в мире по величине экономика, всеобщая грамотность, самая лучшая система образования, первые в мире лазер, синхрофазотрон, зонды на Луну, Марс, Венеру, луноход, ядерный реактор, атомная электростанция, атомный ледокол и т.д. И только когда советские граждане, отказавшись от высших ценностей и смыслов, озаботились ростом все того же благосостояния-потребления, прежде непобедимая, стоявшая во главе мирового научно-технического прогресса советская цивилизация быстро пришла к кризису и катастрофе.

Увы, сменившая марксизм-ленинизм идеология западнизма (рыночного либерализма) заставила нас надежно забыть о масштабных социально-экономических дости- 
жениях и научно-технических прорывах. Хуже того, отказ от советской идеологии в пользу прозападной либерально-рыночной системы ценностей де факто вверг весь бывший СССР с его тихим и скучным «застоем» в бурную череду нескончаемых кризисов, девальваций, дефолтов, инфляционных шоков, терактов, цветных революций, гражданских войн и прочих неведомых нам ранее радостей всепобеждающего рыночного капитализма.

Приходится признать, что в мире, по большому счету, существуют всего лишь две великие мировоззренческие, идеологические альтернативы, сводящиеся к выбору между потреблением и жертвованием. Первая альтернатива, абсолютизирующая потребности человека, лежит в фундаменте идеологии западнизма во всех ее проявлениях. К сожалению, она объективно толкает цивилизацию на бесконечную борьбу людей и народов не только друг с другом, но и с природой за дефицитные средства существования. Тем самым западный путь развития чреват социальными потрясениями, войнами, нарастанием терроризма, усугублением экологических проблем. Он объективно ведет цивилизацию в тупик, к глобальному конфликту и системному кризису, очертания которого сегодня уже отчетливо просматриваются.

Избежать грядущей глобальной катастрофы возможно только в рамках иной мировоззренческой, идеологической альтернативы, которая формировала бы понимание необходимости осознанного самоограничения потребностей (жертвования благосостоянием) ради других людей, во имя будущего наших детей и внуков, ради выживания человечества в целом. Неслучайно именно самоограничение, жертвование является стержневой идеей подавляющего большинства несветских, религиозных идеологий.

Таким образом, центральная, стержневая идея новой спасительной для нашей цивилизации идеологии может быть выражена следующей формулой:

$$
\begin{gathered}
\text { Выэнивание и дальнейшее развитие изивилизации }= \\
\text { = Сознательное самоограничение потребностей }+ \\
+ \text { Солидарньй коллективизм в решении общух проблем. }
\end{gathered}
$$

\section{ВЫВОДЫ}

Цели и результаты экономической практики во многом определятся мировоззрением людей, то есть системой присущих им представлений об окружающем их мире, совокупностью значимых для них ценностей, ориентиров и приоритетов. Следовательно, идеологию, позволяющую формировать мировоззрение у большого количества людей и тем самым целенаправленно управлять их социально-экономической активностью, следует рассматривать в качестве ключевой экономической категории.

В условиях глобализации роль идеологии претерпевает кардинальные изменения. Из института, обеспечивавшего выживание отдельных стран и народов, она превращается в действенный инструмент новой колонизации, посредством которого одни державы и народы получают возможность эксплуатировать других. Насаждаемая современному миру идеология рыночного либерализма обеспечивает процветание нескольких западных стран за счет превращения остального мира в донора дешевых сырьевых и интеллектуальных ресурсов для них.

Подобное мироустройство, подразумевающее стремление к удовлетворению безграничных потребностей человека и соответственно бесконечный конфликт людей друг с другом и с природой, ведет человечество к эскалации социально-экономических, военно-политических, экологических противоречий, к системному глобальному кризису и катастрофе. Преодоление этих противоречий возможно в рамках иной мировоззренческой, идеологической альтернативы, ориентирующей человечество не на абсолюти- 
зацию его потребностей, а на осознание необходимости сознательного самоограничения потребностей и жертвования благосостоянием во имя выживания человечества.

\section{ЛИТЕРАТУРА}

1. Лемещенко, П.С. Институциональная экономика: теория, политика, практика: учеб. пособие. - Минск: Мисанта, 2015. - 699 с.

2. Лемещенко, П.С. Институциональная составляющая идеологии в экономике и науке / П.С. Лемещенко // Институциональные закономерности устройства и эволюции социально-экономической системы Беларуси: Материалы и доклады научной конференции (г. Минск, 21 мая 2004 г.): в 2 ч. - Ч. 1. - Минск: Бестпринт, 2004. - С. 5-30.

3. Руденков, И.А. Идеология, политэкономия, институты / И.А. Руденков // Институциональные закономерности устройства и эволюции социально-экономической системы Беларуси: Материалы и доклады научной конференции (г. Минск, 21 мая 2004 г.): в 2 ч. - Ч. 1. - Минск: Бестпринт, 2004. - С. 51-60.

4. Социодинамика Беларуси, России и Украины: политико-экономический аспект / П.Г. Никитенко, С.Ю. Солодовников; Ин-т экономики Нац. акад. наук Беларуси. Минск: Беларус. навука, 2010. - 557 с.

5. Осипов, Ю.М. Обретение / Ю.М. Осипов. - М.: Теис, 2011. - 591 с.

6. Зиновьев, А.А. Русская трагедия / А. Зиновьев. - М.: Алгоритм, 2014. - 464 с.

7. Шмелев, Н.П. Некоторые ключевые российские вопросы, ответа на которые пока нет / Стратегия выбора, выбор стратегии: Матер. науч. конф. - М.: МГУ им. М.В. Ломоносова, 2003. - С. 10-22.

8. Полторанин, М. Власть в тротиловом эквиваленте. Наследие царя Бориса / М. Полторанин. - М.: Эксмо: Алгоритм, 2010. - 512 с.

9. Перкинс, Дж. Исповедь экономического убийцы / Дж. Перкинс. - М.: Претекст, 2012. - 352 с.

10. Дарвин, Ч. Происхождение видов путем естественного отбора, или Сохранение благоприятствуемых пород в борьбе за жизнь / Ч. Дарвин. - С.-Петербург: Наука, 1991. -455 c.

11. Кропоткин, П.А. Взаимная помощь как фактор эволюции / П.А. Кропоткин. С.-Петербург, 1907. - 352 с.

12. Дарвин, Ч. Происхождение человека и половой отбор / Ч. Дарвин; Пер. с англ. проф. И. Сеченова. - С.-Петербург: Типография И.Н. Скороходова, 1896. - 425 с.

Статья поступила в редакциию 15 декабря 2015 года. 